
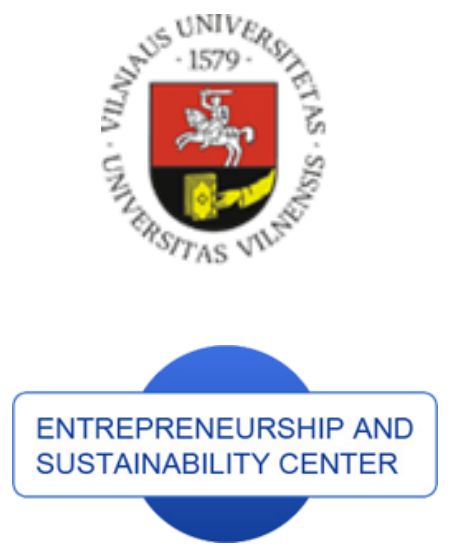

Publisher

http://jssidoi.org/esc/home
ISSN 2345-0282 (online) http://jssidoi.org/jesi/

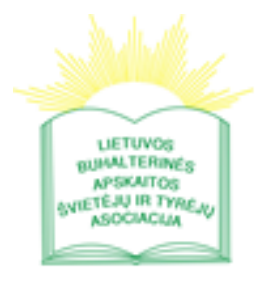

enterprise

* europe

network

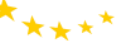

Business Support on Your Doorstep
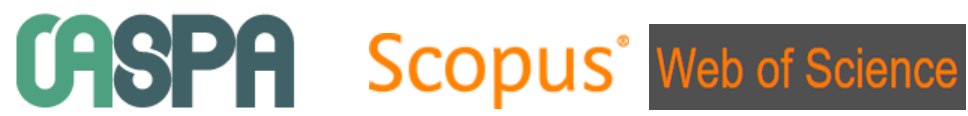

\title{
INFORMATION SUPPORT OF THE CIRCULAR ECONOMY: THE OBJECTS OF ACCOUNTING AT RECYCLING TECHNOLOGICAL CYCLE STAGES OF INDUSTRIAL WASTE
}

\author{
SvetlanaVegera $^{1}$, Alena Malei $^{2}$, Ina Sapeha ${ }^{3}$, Volha Sushko ${ }^{4}$ \\ 1,2,3,4 Polotsk State University, Novopolotsk, Blohina str.29, The Republic of Belarus \\ E-mails:1'svegera@mail.ru; ${ }^{2}$ maleialena@yandex.by; ${ }^{3}$ golden135@yandex.by; ${ }^{4}$ sush.olga@rambler.ru;
}

Received 28 March 2018; accepted 20 May 2018; published 30 September 2018

\begin{abstract}
Circular economy is one of the imperatives of sustainable development of production and society as a whole, which poses corresponding challenges to existing accounting system. In modern conditions of transition from industrial to post-industrial economy, the problem of maintaining a favorable environment and rational use of natural resources requires an adequate transformation of accounting methodology, oriented to the reproduction and sustainable use of natural resources, and not maximum revenue from their exploitation. At present, there is no complete system of accounting for production waste, which would allow solving tasks, which are set by the circular economy, which determines the relevance of the research topic. The purpose of this research is the determination of technological cycle stages of industrial waste and the identification of accounting objects arising at these stages for further recommendations development of industrial waste assessment and accounting for the curcular economy purposes. Among the methods used in the study, the authors identify synthesis, analysis, comparison, logical generalization, inference by analogy, classification, grouping etc. In this article, technological cycle stages of industrial waste will be considered (Stage 1 "Appearance", Stage 2 "Collection and Accumulation", Stage 3 "Waste Preparation for Use", Stage 4 "Storage", Stage 5 "Use", Stage 5 "Burial (destruction)" and identified the objects of their accounting: waste of ferrous and non-ferrous metals, construction waste, waste arising from reservoirs cleaned), as well as costs due to the specifics of technological cycle stage.
\end{abstract}

Keywords: industrial waste; technological cycle; costs; waste of ferrous and non-ferrous metals; construction waste and waste arising from reservoirs cleaned

Reference to this paper should be made as follows: Vegera, S.; Malei, A.; Sapeha, I.; Sushko, V. 2018. Information support of the circular economy: the objects of accounting at recycling technological cycle stages of industrial waste, Entrepreneurship and Sustainability Issues 6(1): 190-210. http://doi.org/10.9770/jesi.2018.6.1(13)

JEL Classifications: M, M4, M41

Additional disciplines: law; ecology and environment; environmental engineering 


\section{Introduction}

One of the indicators of sustainable development proclaimed by United Nations is the requirement to significantly reduce waste generation by 2030 through the prevention, reduction, recycling and reuse [1]. Accordingly, in conditions of getting closer to the goal of providing sustainable patterns of consumption and production, the circular economy is the imperative in modern society. This economy has a restorative and withdrawn character [2]. The circular economy is designed to replace the linear "take, make, dispose" economic model with the "take, make, reuse" model. It is characterized by minimization of consumption of primary raw materials and volumes of processed resources, reduction of waste directed to disposal, while reducing the area occupied by the relevant landfills [3]. According to Achim Steiner, the head of the United Nations' Development Program, with the implementation of the circular economy principles, world economic growth can become stable and fair, and the welfare of all countries can increase, while reducing global consumption of materials and energy [4]. The experts who signed the Summary of the World Circular Economy Forum 2017 (Finland, Helsinki) agree that the circular economy offers significant benefits, including economic, environmental and social benefits such as increased profits, lower carbon emissions, cleaner production methods and creation of new jobs. However, the transition to the circular economy requires a completely new thinking, as well as a new approach to the process of product development [4].

For the Republic of Belarus, the issues of ecology and waste management are also relevant, as more than 40 million tons of waste are generated annually [5]. The National Strategy for Sustainable Social and Economic Development of the Republic of Belarus for the period up to 2030 defines the strategic goal of the state policy of the country in the field of waste management in three key areas, which correspond to the the circular economy principles:

1) The maximum reduction in waste generation in all sectors of the economy,

2) Prevention of harmful impact of waste on the environment and health of citizens,

3) The most complete involvement of waste in the economic circulation as a secondary raw material.

The neccessity in protection of human from himself and the results of the technogenic revolution was proclaimed by the Declaration of the United Nations Conference on the Human Environment in 1972. It says: "The protection and improvement of the human environment for present and future generations has become a major goal of humanity - the goal that must be achieved jointly and in accordance with established and basic goals of peace and international economic and social development".

Despite the fact that this happened more than 45 years ago, significant changes in economic relations, reflecting the principles of environmental management, including the widespread implementation of the circular economy, are still at the stage of its development. At the same time, the development in different economic knowledge sectors is proceeding at different rates, somewhere faster, somewhere slower. The obvious lag is traced in accounting system, since no such tasks have been set up to date. However, the implementation of the circular economy requires some information base both for analyzing its development and for personalizing responsibility for the results of economic activity, identifying their (not) correspondence with the declared principles of full involvement of waste in economic circulation as secondary raw materials at the level of each business entity.

While investigating the development of environmental and economic thought and its impact on the accounting system, the Ukrainian scientist I.V. Zamula stresses that ignoring environmental problems is due to people's behavior, which corresponds to maximization of profits. Being the basis of the behavior of "homo economicus", economic rationality predetermined the pragmatic nature of accounting. The basis of the industrial economy was the scale of production, which ensured competitiveness in the market. In this connection, corresponding 
The International Journal

ENTREPRENEURSHIP AND SUSTAINABILITY ISSUES

ISSN 2345-0282 (online) http://jssidoi.org/jesi/

2018 Volume 6 Number 1 (September)

http://doi.org/10.9770/jesi.2018.6.1(13)

development of accounting methods, in particular cost accounting and calculation, has become the efficiency ensurance of an enterprise in the industrial society, has armed the economic entities in their competitive opposition [6, p. $47-48]$.

Strengthening profit maximization principle based on the spread of the principle in the economic theory of rationality contributed to the elimination of the owner of capital interest in saving the environment. Modern economic theory consolidated such a system of economic motives, goals and principles of their implementation, which favored destructive tendencies in the process of human development [6, p.76 - 77].

Thus, an important feature of the industrial economy influence on the accounting system was the idea, that economic growth and profit maximization did not require accounting to generate information on the environmental performance of activities and their impact on economic indicators both at the micro- and at macrolevels. Maximization of profit and equity of an individual organization was often carried out due to the predatory use of the natural factor, the deterioration of the ecological state of natural resources, in other words, at the expense of natural capital as part of public national wealth.

In modern conditions of transition from industrial to post-industrial economy, the problem of maintaining a favorable environment and rational use of natural resources requires an adequate transformation of the accounting methodology, oriented to the reproduction and sustainable use of natural resources, and not the maximum revenue from their exploitation [7].

At present, there is no complete accounting system for production waste, which would allow solving the tasks set by the circular economy. Despite the fact that the issues of accounting and waste assesment are reflected in some legal documents and economic literature, there are a number of unexplored issues in this area, which causes the relevance of the chosen topic.

In particular, in economic and normative literature there is only a general approach that does not take into account the specific nature of various kinds of waste. Investigating the practice of economic entities on waste management has shown that this is an extremely expensive process. Many of them account it according to the classical canons as a production process, but such an approach is not acceptable to waste, since it acts as a demotivating factor. The product obtained as the result of waste processing estimated by the cost method can not be realized on the market with the costs incurred. In this regard, completely different approaches are required to organize the accounting of waste and costs associated with their circulation, which poses the appropriate challenges to the existing accounting system.

At the same time, for the development of an integrated system for assesment, documentation, synthetic and analytical waste accounting, it is necessary initially to clearly identify the relevant accounting objects throughout the entire process of waste management, to develop principles and methodological approaches for building an integrated system for the accounting of industrial waste.

The purpose of this study is to distinguish technological cycle stages of industrial waste recycling and to identify the accounting objects at these stages. Setting of the purpose has determined the necessity of solving following problematic aspects: classification of industrial waste as an objects of accounting; determination of the technological cycle stages of industrial waste; identification of accounting objects at technological cycle stages of industrial waste in order to develop further recommendations for assessment and accounting of industrial waste. The object of the research is industrial waste at technological cycle stages in the petrochemical complex. 


\section{The International Journal}

ENTREPRENEURSHIP AND SUSTAINABILITY ISSUES

ISSN 2345-0282 (online) http://jssidoi.org/jesi/

2018 Volume 6 Number 1 (September)

http://doi.org/10.9770/jesi.2018.6.1(13)

In the conducted research, the following methods of scientific research are used: analysis and synthesis, comparison, logical generalization, inference by analogy, classification, grouping, etc. Theoretical basis of the research was standards in the field of environmental management, regulatory framework for waste management in the Republic of Belarus and countries of the European Space, special foreign and domestic economic literature on environmental protection, environmental management and "green" accounting.

Recently, enterprises are increasingly faced with a serious problem of increasing the amount of waste generated and reducing the space for their disposal. The governments around the world demonstrate the importance of developing strategies aimed to the competent waste management, streamlining their accounting system, as well as taking into account the environmental costs of waste disposal and the restoration of material resources in circular economy. However, research in this area is limited.

The search for solutions to the problems of developing an integrated waste management system and developing methodology for its implementation has been the object of scientific research by foreign and domestic authors. In particular, the following authors considered the issues of waste management in the context of circular economy: M. Bartolomeo [8], R. H. Gray [9], [10], [11], P. Bartelmus, E.K. Seifert [12], A. Tisserant, S.Pauliuk, S. Merciai, J. Schmidt, J. Fry, R. Wood, A. Tukker [13], M.G. Baldarelli, N. Nesheva-Kiosseva [14], K. Uno, P. Bartelmus [15], A. B. Gala [16], J.S. Krones [17], N. Kirboe, H. Sramkova, M. Krarup [18], D. Gallaud, B. Laperche [19], McKinsey [20], R.C. Brears [21], B. Muys [22], Wen-Hong Zhang [23], Si-Yi Qin, Bing Hao [24], Liang Dai [25], Jing-Chi Guo [26], Du C.L. [27], Y. Geng, X.B. Wang, Q.H. Zhu, H.X. Zhao [28], L.H. Hao, H.M. Xie, M. Huang, M.X. Lu, S.B. Yao [29], P. Heck [30], S. Wang [31], K. Parajuly [32], Y.I. Vaisman, O.A. Tagilova, E.L. Sadokhina [33]. The works of these scientists have made a significant contribution to the development of methodological recommendations for waste management, the issues of their recycling, utilization and disposal. Among the issues that are reflected in these works can also be identified: the analysis of historically established approaches to solving waste management problems, the conceptual framework, alternative sources and tools of environmental accounting in the context of circular economy, the experience of various countries in this area, the actions taken to protect the environment and their consequences, as well as tools and reporting standards (ISO, GRI). A lot of attention is paid to environmental safety at macro level and despite the availability of research and development in these areas, there are some unsolved questions on the integration of economic and environmental accounting at micro level.

No less attention is paid to the issue of waste management costs, environmental protection costs arising from the activities of enterprises. Interest in this topic is actively present in the world scientific field since the end of the 20th century and is reflected in the works of the following authors: R.T. Enander [34], M. Dutta [35], William D. Robinson [36], Paul N. Cheremisinoff [37], M.D. Ivanova [38], L.A. Nasakina [39], A.N. Brylev [40], L.V. Chhutiashvili [41], Z.S. Tysyakova, A.A. Chertkova [42], Ch. Jasch [43], Giuseppe D'Onza, Giulio Greco, Marco Allegrini [44], R. Jachnik [45], Kely Cristina Passarini, Maria Aparecida Pereira, Thiago Michel de Brito Farias, Felipe Araújo Calarge, Carlos Curvelo Santana [46]. The purpose of these works was to implement a tool for managing environmental costs - calculating the cost of collecting various types of waste, their recycling and disposal. The problematic issues of the implementation procedures for the formation of environmental costs and their reflection in accounting were thoroughly studied. The analysis of previous studies and research in this area allowed us to conclude that the main lack of modern studies of the specific nature of environmental protection costs is that they focus mainly on the cost component of the main types of activity. The costs of environmental activities in the process of their accounting are distributed both to the finished product and to the balances of the work in progress.

The development and streamlining of the industrial waste accounting system has been studied by Woodard \& Curran, Inc. [47], Lawrence K. Wang, Yung-Tse Hung, Howard H. Lo, Constantine Yapijakis [48], D.O. 
The International Journal

ENTREPRENEURSHIP AND SUSTAINABILITY ISSUES

ISSN 2345-0282 (online) http://jssidoi.org/jesi/

2018 Volume 6 Number 1 (September)

http://doi.org/10.9770/jesi.2018.6.1(13)

Gricishen [49], S.I. Pronin [50], E.P. Volynkina [51], N.N. Rubanova [52], M.A. Grosheva [53], R.Z. Umerov [54], O.V. Lapytova [55], M.P. Cheysova [56], V.I. Petukhov, O.L. Litvinec, A.V. Taskin, A.S. Holodov, S.I. Ivannikov [57], E.A. Antanenkova [58], T.M. Panchenko [59]. These studies underscore the negative impact of industrial enterprises on the environment in terms of industrial waste generation. The peculiarities of accounting for industrial wastes and environmental costs associated with their treatment are reflected.

There is no doubt that there are many studies in the field of waste management. However, it is necessary to mention that all studies are quite fragmentary. Part of the research is devoted to general waste issues, for example, environmental management, some consider the issues of waste management in the context of the competent formation of environmental costs and their reflection in the accounts. Proceeding from the set of research results, the authors concluded that there is no development of an integrated accounting system for handling industrial waste that would include general aspects (waste collection, recycling, utilization and disposal), the reflection of industrial waste as objects of accounting and accounting of costs connected with waste treatment. The lack of developments in this issue determines the relevance of the chosen topic.

\section{Classification of industrial waste for accounting purposes}

The most important prerequisite for the organization of accounting is a scientifically based classification, which makes it advisable to develop classification of industrial waste of petrochemical complex.

According to the Law of the Republic of Belarus "On Waste Management" No. 271-3, wastes are substances or objects formed in the process of carrying out economic activity, human activity and that do not have a specific purpose at the place of their formation, or have lost their consumption properties in whole or in part [60]. In accordance with this Law, waste is divided into types depending on:

1) By origin - production waste and consumption waste

2) By aggregate state - solid and liquid waste;

3) By possibility of their use - secondary material resources and other wastes of production and consumption. Based on the study of waste classification approaches in the regulatory and legal acts of the Republic of Belarus, five levels of waste classification can be identified as basic and common to all types of waste:

Table 1. The main levels of waste classification for accounting purposes

\begin{tabular}{|c|l|l|}
\hline The level & \multicolumn{1}{|c|}{ Classification sign } & \multicolumn{1}{c|}{ Type of waste } \\
\hline 1 & By origin & $\begin{array}{l}\text { Production waste; } \\
\text { Consumption waste. }\end{array}$ \\
\hline 2 & According to the aggregate state & $\begin{array}{l}\text { Solid waste; } \\
\text { Liquid waste; }\end{array}$ \\
\hline 3 & By place of origin & $\begin{array}{l}\text { Depending on the specific process, where these waste occur: } \\
\text { construction, reconstruction, cleaning of reservoirs, etc. }\end{array}$ \\
\hline 4 & By possibility for further use & $\begin{array}{l}\text { Secondary material resources; } \\
\text { Other waste products of production and consumption. }\end{array}$ \\
\hline 5 & $\begin{array}{l}\text { On the need for further processing } \\
\text { for use }\end{array}$ & $\begin{array}{l}\text { Used after recycling; } \\
\text { Used without recucling. }\end{array}$ \\
\hline 6 & By class and degree hazards & According Decision No. 1391 [61] \\
\hline
\end{tabular}

Source: authors' own development based on The Law No. 271-3 [60], Decision No. 1391 [61]

At the same time, different kinds of waste will have their own classification peculiarities for accounting purposes, which will be considered further. 
The International Journal

ENTREPRENEURSHIP AND SUSTAINABILITY ISSUES

ISSN 2345-0282 (online) http://jssidoi.org/jesi/

2018 Volume 6 Number 1 (September)

http://doi.org/10.9770/jesi.2018.6.1(13)

For the purpose of this study, the authors will consider industrial waste, which is the waste produced during the implementation by economic entities (production of products, energy, performance of work, provision of services), by-products and associated products of mining and mineral processing, cause the interest [60].

A number of policy documents regulates activity connected with industrial waste management in the Republic of Belarus. State regulation and management in the field of waste management is carried out by the President of the Republic of Belarus, the Council of Ministers of the Republic of Belarus, as well as the Ministry of Natural Resources and Environmental Protection of the Republic of Belarus, the Ministry of Housing and Communal Services of the Republic of Belarus, the Ministry of Health of the Republic of Belarus, the Ministry of Emergency Situations of the Republic of Belarus, Ministry of Trade of the Republic of Belarus, Ministry of Finance of the Republic of Belarus, local Councils of Deputies, month executive and administrative bodies, other state bodies within their competence, as defined by law.

Despite the existence of legislative acts and scientific research in the field of waste management in the Republic of Belarus, there are a huge number of controversial issues connected with specificity of various types of waste. Our research is based on accounting practices of organizations of the Vitebsk region in the Republic of Belarus. The Vitebsk region is a highly developed industrial region in Belarus. In 2017, the industry is represented by 1,548 enterprises of various industries, trade - 3,823 enterprises, transport and communications - 1495 enterprises. The production of petroleum products defines the structure of industrial production in the region: in 2017, 50\% of the region's industrial output.

As a result of research accounting practice of production waste, the authors has identified three groups of waste, which have a number of controversial issues in assesment, identification and reflecting in the accounts:

1) scrap and waste of ferrous and non-ferrous metals (group of wastes from metals and their alloys);

2) construction waste (group of wood waste, waste of pulp, paper, cardboard, mineral waste (excluding metal waste, waste of plastics, rubber-containing waste));

3) waste arising from cleaning of reservoirs (group of wastes from oil-refined products).

All types listed above of industrial waste are of the interest for this research, since they have their own specific features that will have a significant impact on their accounting system construction.

Let's consider the classification of industrial waste types mentioned in petrochemical complex for accounting purposes.

Instruction No. 98/12/10 specifies that scrap and waste of ferrous and non-ferrous metals are equipment that has become unusable or has lost its operational value, units and assemblies, products made of ferrous and non-ferrous metals, production waste from ferrous and non-ferrous metals, and also an incorrigible marriage arising in the course of their production [62]. This type of waste includes Group II wastes. "Wastes from metals and their alloys", presented in Table 2. Depending on metal prevailing in scrap metal, as well as physical characteristics, chemical composition, quality characteristics, carbon content, scrap metal is divided into classes, groups, varieties and species. In accordance with section 4 "Classification and designation" STB 2026-2010, scrap metal is classified according to classes, categories, quality indicators, and the content of alloying elements. The classification of scrap and waste of ferrous and non-ferrous metals is presented below: 
Table 2. Proposed classification of scrap and waste of ferrous and non-ferrous metals

\begin{tabular}{|c|c|c|}
\hline Classification sign & \multicolumn{2}{|c|}{ Type of scrap and waste of ferrous and non-ferrous metals } \\
\hline By origin & \multicolumn{2}{|c|}{$\begin{array}{l}\text { 1. Production waste; } \\
\text { 2. Consumption waste. }\end{array}$} \\
\hline $\begin{array}{l}\text { According to the } \\
\text { aggregate state }\end{array}$ & \multicolumn{2}{|l|}{ 1. Solid waste. } \\
\hline By place of origin & \multicolumn{2}{|c|}{$\begin{array}{l}\text { 1. Liquidation; } \\
\text { 2. Repair and maintenance; } \\
\text { 3. Reconstruction, modernization, restoration; } \\
\text { 4. Installation, dismantling; } \\
\text { 5. The main production process; } \\
\text { 6. Other auxiliary and service production. }\end{array}$} \\
\hline $\begin{array}{l}\text { By possibility for } \\
\text { further use }\end{array}$ & \multicolumn{2}{|c|}{ 1. Secondary material resources. } \\
\hline By degree hazards & \multicolumn{2}{|l|}{$\begin{array}{l}\text { 1. Hazardous; } \\
\text { 2. Not hazardous. }\end{array}$} \\
\hline By composition & \multicolumn{2}{|c|}{$\begin{array}{l}\text { 1. Waste of ferrous and non-ferrous metals, separated clean; } \\
\text { 2. Waste of non-ferrous metals (cable products); } \\
\text { 3. Waste of ferrous and non-ferrous metals in combination products. }\end{array}$} \\
\hline \multirow{2}{*}{ By class } & \multirow[t]{2}{*}{ Carbon content } & Steel scrap \\
\hline & & Scrap iron \\
\hline \multirow[t]{2}{*}{ By category } & \multirow{2}{*}{$\begin{array}{l}\text { By the presence of } \\
\text { alloying elements }\end{array}$} & Carbon scrap (designated by the letter A) \\
\hline & & Scrap metal alloy (denoted by the letter B) \\
\hline \multirow[t]{5}{*}{ By species } & \multirow{5}{*}{$\begin{array}{l}\text { According to the } \\
\text { characteristics and } \\
\text { quality indicators. } \\
\text { (denoted by letters) }\end{array}$} & $\begin{array}{l}\text { K - scrap metal with increased quality indicators in terms of } \\
\text { dimensions and characteristics }\end{array}$ \\
\hline & & M - scrap metal with increased clogging \\
\hline & & $\mathrm{H}$ - scrap metal and (or) unsorted \\
\hline & & $\begin{array}{l}\text { C - scrap metal with reduced quality indicators in terms of } \\
\text { dimensions and characteristics }\end{array}$ \\
\hline & & SR - scrap metal (shredded) \\
\hline
\end{tabular}

Source: authors' own development based on STB 2026-2010. Secondary black metals. General specifications [63]

The second group of industrial waste in petrochemical complex is construction waste. Construction waste is waste, generated during the implementation of economic activities by legal entities and individual entrepreneurs for the erection, reconstruction, capital and current repair, restoration, improvement, installation, dismantling and demolition of buildings and structures, industrial objects, roads, engineering and other communications, including the implementation of organizational and technical measures, special, installation and commissioning [64]. Based on the study of normative and legal acts of the Republic of Belarus regulating waste management, as well as the instruction on waste management of petrochemical enterprise, the authors present the classification of construction waste:

Table 3. Proposed classification of construction waste

\begin{tabular}{|l|l|}
\hline \multicolumn{1}{|c|}{ Classification sign } & \multicolumn{1}{c|}{ Type of construction waste } \\
\hline By origin & $\begin{array}{l}\text { 1. Production waste; } \\
\text { 2. Consumption waste. }\end{array}$ \\
\hline $\begin{array}{l}\text { According to the aggregate } \\
\text { state }\end{array}$ & $\begin{array}{l}\text { 1. Solid waste; } \\
\text { 2. Liquid waste. }\end{array}$ \\
\hline By place of origin & $\begin{array}{l}\text { 1. Construction site; } \\
\text { 2. The site of production of construction, installation, repair and other works. }\end{array}$ \\
\hline By type of work performed & $\begin{array}{l}\text { 1. Liquidation; } \\
\text { 2. Repair and maintenance; } \\
\text { 3. Reconstruction, modernization, restoration; }\end{array}$ \\
\hline
\end{tabular}




\begin{tabular}{|l|l|l|}
\hline \multicolumn{1}{|c|}{ Classification sign } & \multicolumn{1}{|c|}{ Type of construction waste } \\
\hline & $\begin{array}{l}\text { 4. Installation, dismantling; } \\
\text { 5. The main production process; } \\
\text { 6. Other auxiliary and service production. }\end{array}$ \\
\hline By possibility for further use & 1. Secondary material resources. & $\begin{array}{l}\text { 2. Other waste (without the possibility of } \\
\text { further use). }\end{array}$ \\
\cline { 2 - 3 } & 1.1. To be used and/or neutralized & $\begin{array}{l}\text { 2.1 To be disposed (placing in storage } \\
\text { tanks, landfills) }\end{array}$ \\
\hline $\begin{array}{l}\text { On the need for further } \\
\text { processing for use (crushing, } \\
\text { sorting, stratification, etc.) }\end{array}$ & $\begin{array}{l}\text { 1. Waste to be processed for } \\
\text { further use; } \\
\text { 2. Waste not to be processed for } \\
\text { further use. }\end{array}$ \\
\hline By directions of possible use & $\begin{array}{l}\text { 1. Waste for production; } \\
\text { 2. Waste for energy; } \\
\text { 3. Waste to perform work, provide services. }\end{array}$ \\
\hline By class and degree hazards & Hazard class 3-4, non-hazardous \\
\hline
\end{tabular}

Source: authors' own development based on The Law No. 271-3 [60], Decision No. 1391 [61], TCP 17.11-10-2014 [64], Resolution No. 85 [65], The Instruction on Waste Management [66]

Next, let's consider the classification of waste arising from cleaning of reservoirs. The organizations' activity in petrochemical complex lead to the formation of waste arising from the cleaning of reservoirs and tanks. Based on the study of existing classification approaches and based on the technology for extracting residual oil products from the cleaning products and their involvement in processing, taking into account the specifics and conceptual features of the received wastes and losses during the cleaning of reservoirs, the authors propose the following classification of such objects:

Table 4. Proposed classification of waste arising from cleaning of reservoirs

\begin{tabular}{|c|c|c|}
\hline Classification sign & \multicolumn{2}{|c|}{ Type of construction waste arising from cleaning of reservoirs } \\
\hline By origin & \multicolumn{2}{|l|}{ 1. Industrial waste. } \\
\hline $\begin{array}{l}\text { According to the aggregate } \\
\text { state }\end{array}$ & \multicolumn{2}{|l|}{$\begin{array}{l}\text { 1. Solid waste; } \\
\text { 2. Liquid waste. }\end{array}$} \\
\hline By place of origin & \multicolumn{2}{|l|}{ As a result of stripping tanks, tanks. } \\
\hline \multirow[t]{4}{*}{$\begin{array}{l}\text { By the stage of the } \\
\text { technological process }\end{array}$} & $\begin{array}{l}\text { 1. Cleaning reservoir, i.e., physically separating } \\
\text { process residue for further storage in an } \\
\text { intermediate tank; }\end{array}$ & \\
\hline & $\begin{array}{l}\text { 2. Temporary storage of the technological } \\
\text { residue in cutting reservoir before accumulation } \\
\text { of sufficient volume for processing; }\end{array}$ & Technological residue; \\
\hline & 3. Recycling of technological residue; & $\begin{array}{l}\text { 1. Secondary raw materials, i.e. potable product (oil } \\
\text { products suitable for use); } \\
\text { 2. Irreversible waste (inorganic part - rust, silt, sand); } \\
\text { 3. Water. }\end{array}$ \\
\hline & 4. Disposal (burial). & Irreversible waste (inorganic part - rust, silt, sand). \\
\hline $\begin{array}{l}\text { On the need for further } \\
\text { processing for use }\end{array}$ & \multicolumn{2}{|c|}{$\begin{array}{l}\text { 1. Waste to be processed for further use (Technological residue); } \\
\text { 2. Waste not to be processed for further use (Inorganic Part). }\end{array}$} \\
\hline $\begin{array}{l}\text { By possibility for further } \\
\text { use }\end{array}$ & \multicolumn{2}{|l|}{$\begin{array}{l}\text { 1. Secondary material resources; } \\
\text { 2. Other waste (without the possibility of further use). }\end{array}$} \\
\hline $\begin{array}{l}\text { By directions of possible } \\
\text { use }\end{array}$ & \multicolumn{2}{|c|}{$\begin{array}{l}\text { 1. When carrying out the main activities in the main production (Organic - paraffin, asphalt, tar, etc.) } \\
\text { containing high-molecular hydrocarbons) } \\
\text { 2. Not possible to use: Bottom sediment (sludge) (non-return waste (inorganic part - rust, silt, sand). }\end{array}$} \\
\hline By class hazards & \multicolumn{2}{|l|}{ Hazard class $3-4$} \\
\hline By degree hazards & \multicolumn{2}{|l|}{$\begin{array}{l}\text { 1. Moderately hazardous; } \\
\text { 2. Low hazardous. }\end{array}$} \\
\hline
\end{tabular}


The International Journal
ENTREPRENEURSHIP AND SUSTAINABILITY ISSUES

ISSN 2345-0282 (online) http://jssidoi.org/jesi/

2018 Volume 6 Number 1 (September)

http://doi.org/10.9770/jesi.2018.6.1(13)

Source: authors' own development based on the Law No. 271-3 [60], Decision No. 1391 [61], Resolution No. 85 [65], The Instruction on Waste Management [66], Order No. 99 [67]

\section{Identification of accounting objects at technological cycle stages of industrial waste}

As practice has shown, one of the most complicated moments of waste management accounting is a long period of time from the moment of waste generation up to the moment of their use. Especially in those cases, when additional processing/recycling and changing the material form are required. In this connection, it is necessary to identify the objects of accounting at technological cycle stages of industrial waste.

The category "technological cycle stages of waste" was involved into the domestic practice of waste management with the interstate standard GOST 30773-2001 "Resource Saving. Waste management. Technological cycle Stages", adopted by the Interstate Council for Standardization, Metrology and Certification (Minutes No. 19 of May 24, 2001). The state standards committees of such countries as the Republic of Belarus, the Russian Federation, Ukraine, Azerbaijan, Armenia, Kazakhstan, Moldova, the Kyrgyz Republic, the Republic of Tajikistan, Turkmenistan, and the Republic of Uzbekistan supported this standard. The standard corresponds to the OECD Resolution on Transboundary Movements of Hazardous Wastes for Regeneration Operations with (92) 39 (adopted by the Council on 30 March 1992), the Basel Convention on the Control of Transboundary Movements of Hazardous Wastes and their Disposal (22 March 1989) [68]. Technological cycle stages of waste are also detailed in the series of international standards ISO 14000 "Environmental Management" [69].

According to GOST 30773-2001, the process of industrial waste generation is considered in relation to the life cycle of products, which is "a set of interrelated processes of successive changes in the state of the product from the beginning of the study and justification of its development until the end of the service life". An appropriate type of waste can be generated at each stage of the product life cycle (Research and development rationale, development, production, operation (including decommissioning, decommissioning, transfer, disposal, destruction) and major repairs). In this case, technological cycle stages of waste from a particular facility begin at the stage of liquidation after the object has been decommissioned.

Technological cycle stage of waste is the sequence of processes for handling specific wastes during the period from their appearance (at the stages of the product life cycle), certification, collection, sorting, transportation, storage (storage), including disposal and / or disposal (disposal) the end of their existence. Separation of technological cycle stages of industrial waste is important not only for organizing the correct waste management process, but also for identifying accounting objects at these stages, since each of them has its own specificity. In general, there are nine stages of the technological cycle of waste, which are presented below:

Table 5. Technological cycle stages of waste according to GOST 30773-2001

\begin{tabular}{|l|l|}
\hline Name of the stage & \multicolumn{1}{c|}{ Content of the stage } \\
\hline 1. Emergence & $\begin{array}{l}\text { The emergence of waste takes place in technological and operational processes, as well as from objects } \\
\text { liquidation. }\end{array}$ \\
\hline $\begin{array}{l}\text { 2. Collection and } \\
\text { Accumulation }\end{array}$ & $\begin{array}{l}\text { Collection and/or accumulation of objects and wastes in designated locations should be carried out on the } \\
\text { territory of the owner or other authorized territory. }\end{array}$ \\
\hline 3. Identification & $\begin{array}{l}\text { Identification of objects and wastes can be visual and/or instrumental in terms of the characteristics, } \\
\text { parameters, indicators and requirements necessary to confirm the compliance of a particular facility or to a } \\
\text { description of it. }\end{array}$ \\
\hline $\begin{array}{l}\text { 4. Sorting (with } \\
\text { neutralization) }\end{array}$ & $\begin{array}{l}\text { Separation and/or mixing of waste according to certain criteria into qualitatively different components. If } \\
\text { necessary, work is carried out on the primary neutralization of objects and waste. }\end{array}$ \\
\hline
\end{tabular}




\begin{tabular}{|c|c|}
\hline Name of the stage & Content of the stage \\
\hline 5. Certification & $\begin{array}{l}\text { When the objects and waste are certified, passports are filled in and catalog descriptions are registered in } \\
\text { accordance with the adopted forms in national standards bodies. }\end{array}$ \\
\hline $\begin{array}{l}\text { 6. Packaging (and } \\
\text { labeling) }\end{array}$ & $\begin{array}{l}\text { Packing of objects and waste is to ensure the integrity and safety of objects and waste in the course of } \\
\text { sorting, loading, transportation, storage, storage in designated locations by means of installed methods and } \\
\text { means (by stacking in containers or other containers, by packaging, by briquetting with appropriate } \\
\text { marking). Particular attention should be paid to packaging and labeling of hazardous objects and wastes }\end{array}$ \\
\hline $\begin{array}{l}\text { 7. Transportation } \\
\text { and storage }\end{array}$ & Transportation and warehousing of objects and waste should be in established (authorized) places. \\
\hline 8. Storage & $\begin{array}{l}\text { Storage of objects and waste should be open, under a canopy, in containers, mines and other sanctioned } \\
\text { places. }\end{array}$ \\
\hline 9. Disposal & $\begin{array}{l}\text { The removal of objects and waste is carried out by recycling (reuse) or disposal (destruction). The first sub- } \\
\text { step of the 9th stage is the utilization of objects and waste. On the sub-stage of recycling, recycling of } \\
\text { defective or obsolete products, their constituent parts and wastes from them by dismantling } \\
\text { (disaggregation), remelting, using other technologies with recycling (recovery) of organic and inorganic } \\
\text { constituents, metals and metal compounds for reuse in national economy, as well as with the elimination of } \\
\text { waste generated again. The second sub-step of the 9th stage of the technological cycle for the elimination of } \\
\text { hazardous wastes and other wastes is their safe disposal at appropriate landfills or destruction if the disposal } \\
\text { of waste threatens the health and lives of people and the environment. }\end{array}$ \\
\hline
\end{tabular}

Source: authors' own development based on GOST 30773-2001 [68]

Technological cycle of waste cannot be the same for all types of waste and implies a sequence of technological processes for the elimination of specific waste. In this regard, not every type of industrial waste passes through all nine stages of the technological cycle, for different waste, some stages can occur simultaneously, and some even do not exist. Thus, waste transportation can occur both at the collection and accumulation stage (stage 2) and at the stage 7 - transportation and storage. Neutralization can be, both at stage 1 and at stage 3. Stage 5: certification in accordance with the legislation of the Republic of Belarus is carried out only in the transport of waste - the movement of waste vehicles, carried out on a contractual basis or on other legal grounds [68]. Stage 7transportation and storage, may be absent altogether. Stage 9 - removal, it is advisable to divide into separate stages: use (for recycling waste) and disposal (destruction) (for non-return). Thus, following the requirements of GOST 30773-2001, the Law No. 371-3 and the practice of waste management in the Republic of Belarus, the following enlarged of technological cycle stages of industrial waste of petrochemical complex that significantly affect the system of their accounting:

Table 6. Proposed intergrated technological cycle stages of industrial waste

\begin{tabular}{|l|l|l|}
\hline Name of the stage & \multicolumn{1}{|c|}{ Contents of the stage } & \multicolumn{1}{|c|}{ Definition } \\
\hline Stage 1: Emergence & $\begin{array}{l}\text { 1) Simultaneously with identification } \\
\text { 2) In some cases simultaneously with } \\
\text { disinfection }\end{array}$ & $\begin{array}{l}\text { Identification of waste: activities related to the determination of the belonging } \\
\text { of a given object to a waste of one or another type, accompanied by the } \\
\text { establishment of data on its hazardous, resource, technological and other } \\
\text { characteristics. Identification includes classification and coding of waste. }\end{array}$ \\
\hline $\begin{array}{l}\text { Stage 2: Collection } \\
\text { and Accumulation }\end{array}$ & $\begin{array}{l}\text { In some cases simultaneously with } \\
\text { disinfection }\end{array}$ & $\begin{array}{l}\text { Activities on the concentration of waste in places of temporary storage of } \\
\text { waste for the purpose of their subsequent disposal }\end{array}$ \\
\hline $\begin{array}{l}\text { Stage 3: Waste } \\
\text { Preparation for Use }\end{array}$ & $\begin{array}{l}\text { Includes sorting, packaging, labeling, } \\
\text { stratification, etc. }\end{array}$ & $\begin{array}{l}\text { A set of technological operations performed with waste to ensure the } \\
\text { subsequent use of waste as a secondary raw material }\end{array}$ \\
\hline Stage 4:Storage & $\begin{array}{l}\text { It is carried out for the purpose of of } \\
\text { further use for recycling waste and } \\
\text { disposal (destruction) for waste that } \\
\text { are impossible to use. }\end{array}$ & $\begin{array}{l}\text { Waste content in places of temporary storage of waste, at waste storage } \\
\text { facilities prior to their transportation to burial sites, disposal of waste and (or) }\end{array}$ \\
waste disposal facilities
\end{tabular}




\begin{tabular}{|l|l|l|l|l|}
$\begin{array}{l}\text { Stage 6: Burial } \\
\text { (destruction/disposal) }\end{array}$ & $\begin{array}{l}\text { 1) Including transportation } \\
\text { transportation of waste 2) including } \\
\text { certification (if there is transportation } \\
\text { / transportation of waste }\end{array}$ & $\begin{array}{l}\text { Waste insulation at waste disposal sites in order to prevent the harmful impact } \\
\text { of waste products of their interaction and (or) decomposition on the } \\
\text { environment, health of citizens, property owned by the state, property of legal } \\
\text { entities and individuals (hereinafter - property), not providing for the } \\
\text { possibility of their further use }\end{array}$ \\
\hline
\end{tabular}

Source: authors' own development based on The Law No. 271-3 [60], GOST 30773-2001 [68]

Accounting objects will arise at each stage of the technological cycle of waste. Accounting objects of industrial waste of petrochemical complex in conditions of application of ecological technologies of their utilization and processing taking into account branch features are:

1) Returnable waste, as it can bring economic benefits to organization in the future, which meets the criteria for recognizing assets, according to The Law "On Accounting and Reporting" [70]. In this case, returnable waste in the context of technological cycle stages is the result of the processes occurring at the relevant stage (ie, the product of the output stage). Recycling waste, according to the order of the Ministry of Industry of the Republic of Belarus of June 5, 2015 No. 273 "On approval of the Methodological recommendations for forecasting, accounting and calculation of the cost of production (goods, works, services) in industrial organizations of the system of the Ministry of Industry of the Republic of Belarus", for their recognition must meet the following criteria:

$>$ presence of material form;

$>$ change (loss) of properties of the original raw materials;

$>$ education in the process of production, performance of work, provision of services;

$>$ further use in the production process (main or auxiliary) with increased costs (reduced yield) or use not for its intended purpose [71].

The remains of material resources, which according to the established technology are transferred to other shops, divisions as a high-grade material for the production of other types of products (works, services) do not belong to recyclable waste.

2) The costs associated with the implementation of a set of measures for the use or disposal of industrial wastes, due to the specifics of each technological cycle stage of waste. It is important to note that such costs arise from the second stage of the technological cycle of the waste. In spite of the fact that waste will be recognized as accounting objects only if the criteria for recognition of assets are fulfilled, irrevocable wastes will not be the object of accounting, since they do not have the ability to bring economic benefits to the organization in the future. However, the costs arising from their disposal will not only be the object of accounting, but also depend on the amount and type of such irretrievable waste. In this regard, it is necessary to keep a rapid accounting of irrecoverable waste in quantitative terms. In the interests of this study, the authors will consider the features of identification of industrial wastes as accounting objects at the allocated integrated stages of the technological cycle in the context of the following types of industrial waste:

1) Scrap and waste of ferrous and non-ferrous metals;

2) Construction waste;

3) Waste arising from cleaning of reservoirs.

\section{1) Scrap and waste of ferrous and non-ferrous metals}

According to Article 25 of The Law No. 271-3, burial of secondary material resources is prohibited.

Therefore, Stage 6 "Burial" in waste management of ferrous and non-ferrous metals will be absent.

The complexity of identifying the objects of accounting for waste of ferrous and non-ferrous metals at the previously mentioned stages, and their registration is because the metals themselves:

$>$ can not always be separated from each other;

$>$ can not always be separated from other materials;

$>$ can not always be distinguished from the composition of the combined product. 
In this regard, the authors consider waste of ferrous and non-ferrous metals in the following order:

a) Waste of ferrous and non-ferrous metals, separated clean;

b) Waste of non-ferrous metals (cable products);

c) Waste of ferrous and non-ferrous metals in combination products.

a) Waste of ferrous and non-ferrous metals, separated clean

At the stage of appearance, the following wastes arise:

$>$ Steel scrap unsorted,

$>$ Cast iron scrap unsorted;

$>$ Alloys of alloy steel in lumpy form are uncontaminated;

$>$ Other scrap and waste of ferrous metals not included in group II A incl. shaving metal, etc.

Wastes of ferrous and non-ferrous metals, separable clean pass through the following stages: Stage 1, Stage 2, Stage 3 and Stage 4. The resulting waste during all stages of the technological cycle does not change its materialmaterial form.

b) Waste of non-ferrous metals (cable products)

Separate attention deserves a scrap of cables, because in their composition, in addition to the metal, there are other materials (plastic, fabric and other metals).

Among the types of waste generated, the following can be identified:

$>$ Cable with aluminum conductors in insulation;

$>$ Cable with copper conductors in isolation.

Waste of ferrous and non-ferrous metals containing foreign material passes through stage 1, stage 2, stage 3 and stage 4. During the use stage, these types of waste change the material-material form.

c) Waste of ferrous and non-ferrous metals in combination products

The division of the combination products into specific components is not possible or economically uneffective. As a part of the combination products, there can be both metals of different types, and other materials (plastic, fabric and other metals). Some types of waste ferrous and non-ferrous metals belong to the class of difficult-todismember (combination) products, when they contain black metal with impurities of non-ferrous metal: copper, brass, bronze, aluminum, etc. Such wastes include: lead accumulators spent intact with not discharged electrolyte, scrap of electric motors and scrap of heat exchanger tubes. Waste of ferrous and non-ferrous metals in the combined products pass through stage 1 , stage 2, stage 3 and stage 4 . The material form of the generated waste changes during the use phase. For example, scrap engine has a composition of copper. When the electric motor is handed over to the metal acceptance organization, they accept two kinds of metal (cast iron and copper).

\section{2) Contruction waste}

Not every type of construction waste passes through all the intergrated stages of technological cycle. This is because construction waste can be both suitable and not suitable for future use. Construction waste for further use may not always be involved in the production process immediately after the collection and/or accumulation stage. Some types of construction waste require processing. During processing, construction waste can change its material-material form, its quantitative and qualitative indicators, which will undoubtedly affect the system of their accounting.

In the practice of the organizations studied, the following groups of construction waste are formed:

$>$ Wood waste;

$>$ Waste pulp, paper, cardboard;

$>$ Waste of mineral origin (excluding metal waste);

$>$ Other wastes of mineral origin, including waste products for refining;

$>$ Waste plastic, rubber-containing waste.

For each indicated group of construction waste, there are specific features of their passage of these stages of the technological cycle of construction waste. Considering these features, we will consider the selected types of construction waste in the context of technological cycle stages, presented in Table 7: 
Table 7. Construction waste at the stages of the technological cycle of industrial waste

\begin{tabular}{|c|c|c|c|}
\hline $\begin{array}{l}\text { Emerging } \\
\text { construction } \\
\text { waste }\end{array}$ & $\begin{array}{l}\text { Construction waste } \\
\text { groups }\end{array}$ & Construction waste types & Technological cycle stages \\
\hline $\begin{array}{l}\text { Construction } \\
\text { waste to be } \\
\text { processed for } \\
\text { further use }\end{array}$ & $\begin{array}{l}\text { Waste of mineral } \\
\text { origin (excluding } \\
\text { metal waste) }\end{array}$ & $\begin{array}{l}\text { Scrap/bout of concrete, expanded clay, } \\
\text { reinforced concrete and brick }\end{array}$ & $\begin{array}{l}\text { Stage 1: Emergence; } \\
\text { Stage 2: Collection and Accumulation; } \\
\text { Stage 3: Waste Preparation for Use; } \\
\text { Stage 4: Storage; } \\
\text { Stage 5: Using. }\end{array}$ \\
\hline \multirow[t]{3}{*}{$\begin{array}{l}\text { Construction } \\
\text { waste not to be } \\
\text { processed for } \\
\text { further use }\end{array}$} & Wood waste & $\begin{array}{l}\text { Sawdust and chips in the manufacture of } \\
\text { carpentry and milled products, wood waste } \\
\text { construction, products made of natural wood, } \\
\text { lost their consumer properties and other }\end{array}$ & \multirow[t]{3}{*}{$\begin{array}{l}\text { Stage 1: Emergence; } \\
\text { Stage 2: Collection and Accumulation; } \\
\text { Stage 4: Storage; } \\
\text { Stage 5: Using. }\end{array}$} \\
\hline & $\begin{array}{l}\text { Waste pulp, paper, } \\
\text { cardboard }\end{array}$ & $\begin{array}{l}\text { Ruberoid waste and paper and cardboard filters } \\
\text { impregnated with petroleum products }\end{array}$ & \\
\hline & $\begin{array}{l}\text { Waste plastic, rubber- } \\
\text { containing waste }\end{array}$ & Polyethylene & \\
\hline \multirow{5}{*}{$\begin{array}{l}\text { Construction } \\
\text { waste to be } \\
\text { disposed } \\
\text { (placing in } \\
\text { storage tanks, } \\
\text { landfills) }\end{array}$} & Wood waste & Contaminated wood waste & \multirow{5}{*}{$\begin{array}{l}\text { Stage 1: Emergence; } \\
\text { Stage 2: Collection and Accumulation; } \\
\text { Stage 4: Storage; } \\
\text { Stage 6: Burial (destruction/disposal). } \\
\text { A shorter technological cycle is also } \\
\text { possible for these types of waste: } \\
\text { Stage 1: Emergence; } \\
\text { Stage 6: Burial (destruction/disposal). }\end{array}$} \\
\hline & $\begin{array}{l}\text { Waste pulp, paper, } \\
\text { cardboard }\end{array}$ & $\begin{array}{l}\text { Paper and cardboard filters impregnated with } \\
\text { petroleum products }\end{array}$ & \\
\hline & $\begin{array}{l}\text { Waste of mineral } \\
\text { origin (excluding } \\
\text { metal waste) }\end{array}$ & $\begin{array}{l}\text { Glass-reinforced glass; Fiberglass fouled; } \\
\text { Waste glass "Triplex"; Sand contaminated with } \\
\text { inorganic substances (acids, alkalis, salts, etc.); } \\
\text { Waste of dry cleaning of garages, car parks, } \\
\text { parking places of transport; Waste products of } \\
\text { heat-insulating asbestos-containing products; } \\
\text { Sludge of gas cleaning }\end{array}$ & \\
\hline & $\begin{array}{lr}\text { Other } & \text { wastes } \\
\text { mineral of } \\
\text { including } & \text { origin, } \\
\text { products for refining }\end{array}$ & $\begin{array}{l}\text { Combined construction waste, construction } \\
\text { waste from building luquidation }\end{array}$ & \\
\hline & $\begin{array}{l}\text { Waste plastic, rubber- } \\
\text { containing waste }\end{array}$ & $\begin{array}{l}\text { Waste glass wool, Wiping material } \\
\text { contaminated with oils (oil content } 15 \% \text { and } \\
\text { more), Waste of paronite Waste ion exchange } \\
\text { resins; Fluoroplastic; Waste of pipes, hoses of } \\
\text { vulcanized rubber }\end{array}$ & \\
\hline $\begin{array}{l}\text { Mixed } \\
\text { construction } \\
\text { waste }\end{array}$ & \multicolumn{2}{|c|}{$\begin{array}{l}\text { Types of construction waste that are subject to further use, during the } \\
\text { processing of which not only new types of construction waste will be } \\
\text { generated (for use), but also waste that is to be buried - no } \\
\text { petrochemical complex is formed }\end{array}$} & $\begin{array}{l}\text { Stage 1: Emergence; } \\
\text { Stage 2: Collection and Accumulation; } \\
\text { Stage 3: Waste Preparation for Use; } \\
\text { Stage 4: Storage; } \\
\text { Stage 5: Using; } \\
\text { Stage 6: Burial (destruction/disposal). }\end{array}$ \\
\hline
\end{tabular}

Source: authors' own development

[72] 
The International Journal

ENTREPRENEURSHIP AND SUSTAINABILITY ISSUES

ISSN 2345-0282 (online) http://jssidoi.org/jesi/

2018 Volume 6 Number 1 (September)

http://doi.org/10.9770/jesi.2018.6.1(13)

\section{3) Waste arising from cleaning of reservoirs}

Among the technological process stages of reservoirs cleaning, extracting residual oil products from the equipment cleaning products and involving them into processing, the following can be singled out:

Stage 1: Emergence (cleaning reservoirs, i.e., physically separating process residue for further storage in an intermediate tank);

Stage 2: Collection and Accumulation (Temporary storage of technological residue in cutting reservoir before accumulation of sufficient volume for processing);

Stage 3: Waste Preparation for Use (Recycling of technological residue, extraction of oil products from cleaning products and their involvement in processing);

Stage 5: Using (in terms of involvement in oil residues processing);

Stage 6: Burial (disposal of waste not possible for further use).

At stage 1, technological residue will be the object in waste accounting, which then goes to step 2, where it is placed in the separation reservoir for further collection and temporary storage in order to accumulate sufficient volume for subsequent processing.

At stage 1, the following accounting items are determined:

$>$ Liquefied residue;

$>$ Technological residue.

It should be noted that the received "liquefied residue" being the object of accounting is not a waste, since it is a full-fledged oil product and is used for its intended purpose.

Technological residue obtained as a result of cleaning reservoir is also subject for accounting.

At stage 3 "Waste Preparation for Use" through the separation and subsequent decontamination, the following accounting objects are formed:

1. Recyclable raw materials used:

Secondary raw materials, i.e. potable product (oil products suitable for use);

2. Non-returnable waste (technological losses), subject to disposal, so-called bottom sediments, sludges) inorganic part (rust, silt, sand, etc.).

In this case, recyclable waste used will be transferred to stage 4 "Use", and irretrievable waste to stage 5 "Burial (destruction/disposal)".

The results of the research will be presented in the table in the context of accounting objects arising at technological cycle stages of petrochemical complex industrial waste:

Table 8. Identification of accounting objects at technological cycle stages of industrial waste

\begin{tabular}{|c|c|c|}
\hline \multirow{2}{*}{$\begin{array}{c}\text { Technological cycle } \\
\text { stages }\end{array}$} & \multicolumn{2}{|l|}{ Accounting objects } \\
\hline & Waste & Costs \\
\hline \multicolumn{3}{|c|}{ SCRAP AND WASTE OF FERROUS AND NON-FERROUS METALS } \\
\hline \multicolumn{3}{|c|}{ Waste of ferrous and non-ferrous metals, separated clean } \\
\hline Emergence & \multirow{5}{*}{$\begin{array}{l}\text { Steel scrap unsorted; Scrap iron cast unsorted; Other scrap } \\
\text { and waste of ferrous metals not included in group II A; } \\
\text { Aluminum scrap unsorted; Copper alloy scrap unsorted; } \\
\text { Bronze scrap unsorted; Scrap of brass unsorted; Scrap and } \\
\text { lead wastes (without lead accumulators) }\end{array}$} & Costs for work performed \\
\hline $\begin{array}{l}\text { Collection and } \\
\text { Accumulation }\end{array}$ & & Costs for collection and accumulation \\
\hline Waste Preparation for Use & & Waste preparation costs for use \\
\hline Storage & & Storage costs \\
\hline Using & & Costs of use \\
\hline \multicolumn{3}{|c|}{ Waste of non-ferrous metals (cable products) } \\
\hline Emergence & \multirow{5}{*}{$\begin{array}{l}\text { Scrap of cable products; Leaded cable and wires with copper } \\
\text { conductors in polyethylene, polystyrene and rubber } \\
\text { insulation; Leaded cable and wires with aluminum } \\
\text { conductors in paper insulation; Cable with aluminum sheath } \\
\text { and copper core }\end{array}$} & Costs for work performed \\
\hline $\begin{array}{l}\text { Collection and } \\
\text { Accumulation }\end{array}$ & & Costs for collection and accumulation \\
\hline Waste Preparation for Use & & Waste preparation costs for use \\
\hline Storage & & Storage costs \\
\hline Using & & Costs of use \\
\hline
\end{tabular}


The International Journal

ENTREPRENEURSHIP AND SUSTAINABILITY ISSUES

ISSN 2345-0282 (online) http://jssidoi.org/jesi/

2018 Volume 6 Number 1 (September)

http://doi.org/10.9770/jesi.2018.6.1(13)

\begin{tabular}{|c|c|c|}
\hline \multirow{2}{*}{$\begin{array}{l}\text { Technological cycle } \\
\text { stages }\end{array}$} & \multicolumn{2}{|l|}{ Accounting objects } \\
\hline & Waste & Costs \\
\hline \multicolumn{3}{|c|}{ Waste of ferrous and non-ferrous metals in combination products } \\
\hline Emergence & \multirow{4}{*}{$\begin{array}{l}\text { Mercury spent thermometers; Mercury lamps used; } \\
\text { Luminescent tubes used; Compact fluorescent lamps (energy- } \\
\text { saving) used; Lead accumulators used intact with not drained } \\
\text { electrolyte; Scrap of electric motors }\end{array}$} & Costs for work performed \\
\hline $\begin{array}{l}\text { Collection and } \\
\text { Accumulation }\end{array}$ & & Costs for collection and accumulation \\
\hline Waste Preparation for Use & & Waste preparation costs for use \\
\hline Storage & & Storage costs \\
\hline Using & Waste of ferrous and non-ferrous metals by types & Costs of use \\
\hline \multicolumn{3}{|c|}{ CONSTRUCTION WASTE } \\
\hline \multicolumn{3}{|c|}{ Construction waste to be processed for further use } \\
\hline Emergence & \multirow[b]{2}{*}{$\begin{array}{l}\text { Waste of mineral origin (excluding metal waste): scrap/bout } \\
\text { of concrete, expanded clay, reinforced concrete and brick }\end{array}$} & Costs for work performed \\
\hline $\begin{array}{l}\text { Collection and } \\
\text { Accumulation }\end{array}$ & & Costs for collection and accumulation \\
\hline Waste Preparation for Use & \multirow{3}{*}{$\begin{array}{l}\text { A new type of waste after recycling: crushed stone of various } \\
\text { fractions, brick crumb, etc. }\end{array}$} & Waste preparation costs for use \\
\hline Storage & & Storage costs \\
\hline Using & & Costs of use \\
\hline \multicolumn{3}{|c|}{ Construction waste not to be processed for further use } \\
\hline Emergence & \multirow{5}{*}{$\begin{array}{l}\text { Different types of wood waste, waste pulp, paper, cardboard, } \\
\text { waste plastic, rubber-containing waste }\end{array}$} & Costs for work performed \\
\hline $\begin{array}{l}\text { Collection and } \\
\text { Accumulation }\end{array}$ & & Costs for collection and accumulation \\
\hline Waste Preparation for Use & & Waste preparation costs for use \\
\hline Storage & & Storage costs \\
\hline Using & & Costs of use \\
\hline \multicolumn{3}{|c|}{ Construction waste to be disposed (placing in storage tanks, landfills) } \\
\hline Emergence & \multirow{4}{*}{$\begin{array}{l}\text { Contaminated wood waste, paper and cardboard filters } \\
\text { impregnated with petroleum products, glass-reinforced glass; } \\
\text { fiberglass fouled; waste glass "triplex"; sand contaminated } \\
\text { with inorganic substances (acids, alkalis, salts, etc.); waste of } \\
\text { dry cleaning of garages, car parks, parking places of } \\
\text { transport; waste products of heat-insulating asbestos- } \\
\text { containing products; sludge of gas cleaning, combined } \\
\text { construction waste, construction waste from building } \\
\text { luquidation, waste glass wool, wiping material contaminated } \\
\text { with oils (oil content } 15 \% \text { and more), waste of paronite waste } \\
\text { ion exchange resins; fluoroplastic; waste of pipes, hoses of } \\
\text { vulcanized rubber }\end{array}$} & Costs for work performed \\
\hline $\begin{array}{l}\text { Collection and } \\
\text { Accumulation }\end{array}$ & & Costs for collection and accumulation \\
\hline Storage & & Storage costs \\
\hline $\begin{array}{l}\text { Burial } \\
\text { (destruction/disposal) }\end{array}$ & & Burial (destruction/disposal) costs \\
\hline \multicolumn{3}{|c|}{$\begin{array}{l}\text { WASTE ARISING FROM CLEANING OF RESERVOIRS } \\
\end{array}$} \\
\hline Emergence & Technological residue & $\begin{array}{l}\text { A) Costs of preparatory work } \\
\text { B) Costs for cleaning } \\
\text { C) Waste material disposal costs }\end{array}$ \\
\hline $\begin{array}{l}\text { Collection and } \\
\text { Accumulation }\end{array}$ & Replenished technological residue & $\begin{array}{l}\text { A) Costs of preparatory work } \\
\text { B) Costs for stripping } \\
\text { C) Waste material disposal costs } \\
\text { D) Costs related to storage losses } \\
\text { E) Taxes and fees } \\
\text { F) Storage costs }\end{array}$ \\
\hline Waste Preparation for Use & Returnable raw materials & $\begin{array}{l}\text { A) Costs for cleaning separation reservoir } \\
\text { and separation of technological residue }\end{array}$ \\
\hline Using & $\begin{array}{l}\text { Recyclable waste: } \\
\text { - Entrapped product; } \\
\text { - Wash water with subsequent use. }\end{array}$ & $\begin{array}{l}\text { A) Additional costs for re-engaging in } \\
\text { turnover } \\
\text { B) Transferring water to treatment } \\
\text { facilities costs }\end{array}$ \\
\hline $\begin{array}{l}\text { Burial } \\
\text { (destruction/disposal) }\end{array}$ & $\begin{array}{l}\text { Irreversible waste to be disposed of (bottom sediments, } \\
\text { sludges) - inorganic part (rust, silt, sand, etc.) }\end{array}$ & $\begin{array}{l}\text { A) Waste transportation costs } \\
\text { B) Storage costs }\end{array}$ \\
\hline
\end{tabular}


The International Journal

ENTREPRENEURSHIP AND SUSTAINABILITY ISSUES

ISSN 2345-0282 (online) http://jssidoi.org/jesi/

2018 Volume 6 Number 1 (September)

http://doi.org/10.9770/jesi.2018.6.1(13)

Source: authors' own development based on The Law No. 271-3 [60], Decision No. 1391 [61], Resolution No. 85 [65], The Instruction on Waste Management [66], GOST 30773-2001 [68]

\section{Conclusions}

Thus, during the conducted research the following tasks were solved:

1. The generalized classification of industrial waste for accounting purposes was presented, and approaches for the classification of certain types of waste were developed: scrap and waste of ferrous and non-ferrous metals, construction waste and waste arising from cleaning of reservoirs;

2. The integrated technological cycle stages of industrial waste were singled out, as well as the features of the separation of these stages in the context of waste types;

3. The authors scientifically substantiated the approaches to identification of accounting objects arising at technological cycle stages: waste and costs, also accounting objects at recycling technological cycle stages of various types of waste were identified: scrap and waste of ferrous and non-ferrous metals, construction waste and waste arising from cleaning of reservoirs.

In future, the results of the research will let the authors develop practical recommendations for industrial waste assessment and accounting for the circular economy purposes.

\section{References}

1. Report of the Secretary-General of United Nations, 2017. "Progress towards the Sustainable Development Goals". High-level political forum on sustainable development, convened under the auspices of the Economic and Social Council: Economic and environmental questions: Sustainable development. July 27-28, Retrieved from https://sustainabledevelopment.un.org/sdg12

2. Ellen MacArthur Foundation, 2015 Delivering the Circular Economy a Toolkit for Policymakers. Retrieved from https://www.ellenmacarthurfoundation.org/assets/downloads/publications/EllenMacArthurFoundation_PolicymakerToolkit.pdf

3. Pahomova, N.V. \& Rihter, K.K. \& Vetrova M.A. 2017. Transition to the circular economy and the closed chain of supply as a factor for sustainable development, Bulletin of St. Petersburg State University. Economy. 33(2): 244-268

4. Makela, T. 2017. Curcular Economy. World Forum of Cyclic Economics (WCEF2017). June 5-7, Helsinki, Finland, Retrieved from https://frontnews.eu/news/ru/3211

5. Decree No. 1061, which approved the National Action Plan for the Development of the Green Economy in the Republic of Belarus

6. Zamyla, I.B. 2010. Accounting of environmental activity in ensuring sustainable development of the economy. Zhytomyr, Zhytomyr region: Zhytomyr State Technological University

7. Malysheva, M. S. 2013. Organization, the Main Directions and Objectives of Economic Analysis Environmental Performance, Contemporary Economic Issues 4. https://doi.org/10.24194/41301 
8. Bartolomeo, M. 2000. Environmental management accounting in Europe: current practice and future potential, European Accounting Review, Vol. 9: pp. 31-52

9. Gray, R. 1993. Accounting for the Environment and Sustainability in Lesser Developed Countries: an explanatory note, Research in Third World Accounting, Vol.2: pp. 387-399

10. Gray, R.H. 2000. Environmental accounting, managerialism and sustainability: is the planet safe in the hands of business and accounting, Advances in Environmental Accounting and Management, Vol.1: pp. 1-44

11. Gray, R. 1997. Green accounting: cosmetic irrelevance or radical agenda for change, Asia-Pacific Journal of Accounting, Vol.4: pp.175-198

12. Bartelmus, P., Seifert $\quad$ E.K. 2018. Green accounting. Retrieved from https://books.google.by/books?id=cepGDwAAQBAJ\&pg=PT305\&dq=industrial+waste+accounting\&hl=ru\&sa=X\&ved=0ahUKEwjfxuLo 29raAhVHzKQKHcV8BIM4FBDoAQhKMAU\#v=onepage \&q=industrial\%20waste\%20accounting \&f=false

13. Tisserant, A., Pauliuk, S., Merciai, S., Schmidt, J., Fry, J., Wood, R., Tukker, A. 2017. Solid Waste and the Circular Economy. Retrieved http://folk.ntnu.no/richardw/papers/Tisserant\%20et\%20al._2017_Journal\%20of\%20Industrial\%20Ecology_Solid\%20Waste\%20and\%20th e\%20Circular\%20Economy\%20A\%20Global\%20Analysis\%20of\%20Waste\%20Treatment\%20and\%20Waste.pdf

14. Baldarelli, M.G., Nesheva-Kiosseva, N. 2017. Environmental Accounting and reporting. Retrieved from https://books.google.by/books?id=3tefDgAAQBAJ\&pg=PA390\&dq=industrial+waste+accounting\&hl=ru\&sa=X\&ved=0ahUKEwiJvsDa2 9raAhVJ6KQKHS1_DZo4ChDoAQhuMAk\#v=onepage \&q=industrial\%20waste\%20accounting \&f=false

15. Uno, K., Bartelmus, P. 1998. Environmental accounting in theory and practice. Retrieved from https://books.google.by/books?id=FpnpCAAAQBAJ\&pg=PA68\&dq=industrial+waste+accounting\&hl=ru\&sa=X\&ved=0ahUKEwjewuS2 29raAhWNyqQKHTbQCxkQ6AEIbDAJ\#v=onepage\&q=industrial\%20waste\%20accounting \&f=false

16. Gala, A.B. 2015. Methodological advacenents in LCA of waste management systems. Retrieved from http://www.tdx.cat/bitstream/handle/10803/289634/abg1de1.pdf?sequence=1

17. Krones, J.S. 2016. Accounting for Non-Hazardous Industrial Waste in the United States. Retrieved from https://dspace.mit.edu/bitstream/handle/1721.1/106591/963240167-MIT.pdf?sequence=1

18. Kirboe, N., Sramkova, H., Krarup, M. 2015. Moving towards a circular economy. Retrieved from https://books.google.by/books?id=m8GPCgAAQBAJ\&printsec=frontcover\&dq=circular+economy\&hl=ru\&sa=X\&ved=0ahUKEwj817firtz aAhXHb1AKHbvJD90Q6AEIPTAD\#v=onepage $\& \mathrm{q}=$ circular\%20economy $\& \mathrm{f}=$ false

19. Gallaud, D., Laperche, B. 2016. Circular Economy. Industrial ecology and short supply chain. Retrieved from $\underline{\text { https://books.google.by/books?id=LbllDAAAQBAJ\&printsec=frontcover\&dq=circular+economy\&hl=ru\&sa=X\&ved=0ahUKEwj817firtza }}$ AhXHb1AKHbvJD90Q6AEIRDAE\#v=onepage \&q=circular\%20economy\&f=false

20. McKinsey\&Company. 2012. Towards the Circular Economy. Retrieved from https://books.google.by/books?id=fYREngEACAAJ\&dq=circular+economy\&hl=ru\&sa=X\&ved=0ahUKEwj817firtzaAhXHb1AKHbvJD9 0Q6AEITTAF

21. Brears, R.C. 2018. Natural resource management and the circular economy. Retrieved from

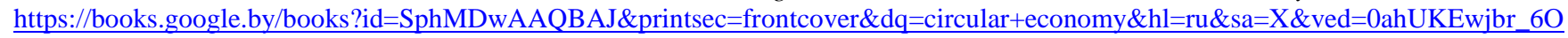
$\underline{\text { sNzaAhWQYVAKHTFEBqU4ChDoAQglMAA\#v=onepage } \& \mathrm{q}=\text { circular\%20economy } \& \mathrm{f}=\text { false }}$

22. Muys, B. 1997. Cleaner production: a guide to information sources. Retrieved from http://www.eea.dk/projects/envwin/manconc/cleanprd/i_2.htm.1997

23. Wen-Hong Zhang. 2005. Eco-industry, circular economy and sustainable development, Journal of Southeast University (Philisophy and Social Science), Vol.7: pp.59-62 
24. Si-Yi Qin, Bing Hao. 2008. Research on the mechanism of circular economy toward environmental protection-sustainable development, Ecological Economy, No. 7: pp. 105-109

25. Liang Dai. 2009. Recycling economy and environmental safety, Renewable Resources and Recycling Economy, Vol.2: pp.29-31

26. Jing-Chi Guo. 2008. The development of circular economy on the promoting function of employment-an example offushun mining group, Coal Economic Research, No. 7: pp. 17-18

27. Du, C.L. 2009. Research on the E-waste Circular Industry in China, Resources Science I: pp.13-17

28. Geng, Y., Wang, X.B., Zhu, Q.H., Zhao, H.X. 2010. Towards a National Circular Economy Indicator System in China: An evaluation and Critical Analysis, Journal of Cleaner Production, No. 23: pp. 216-224

29. Hao, L.H., Xie, H.M., Huang, M., Lu, M.X., Yao S.B. 2009. Implementing China's Circular economy Concept at the Regional Level: A Review of Progress in Dalian, China, Waste Management, No. 29: pp. 996-1002

30. Heck, P. 2006. On the Index System of Cities' Sustainable Development Based on the Circular Economy, Reformation and Strategy, No. 25(9): pp.97-101

31. S. Wang. 2009. Learning Necessity of Setting up a Circular Economy from Chinese Pollution Control Data, Pollution Control, No. 10: pp. 26-29

32. Parajuly, K. 2017. Circular Economy in E-waste Management: Resource Recovery and Design for End-of-Life. Retrieved from https://books.google.by/books?id=Ys2XtAEACAAJ\&dq=circular+economy\&hl=ru\&sa=X\&ved=0ahUKEwi_6MLhsNzaAhXGL1AKHaS UDQc4HhDoAQhhMAk

33. Vaisman, Y.I., Tagilova, O.A., Sadokhina, E.L. 2013. Development of Methodological Principles of Creation and Optimization of Waste Traffic Account for the Purpose of Increasing its Environmental, Economic and Social Management. Ecology and Industry of Russia, Vol. 12: pp. 40-45

34. Enander, R.T. 1996. Hazardous Waste Tracking and Cost Accounting Practice. Retrieved from https://books.google.by/books?id=y2dnrEnqfIEC\&pg=PA122\&dq=waste+cost+accounting\&hl=ru\&sa=X\&ved=0ahUKEwjq47erw9zaAh WOaFAKHWhEAzQQ6AEIOzAD\#v=onepage \&q=waste\%20 cost $\% 20$ accounting $\& \mathrm{f}=$ false

35. Dutta, M. 2004. Cost Accounting: Principles And Practice. Retrieved from https://books.google.by/books?id=SDtixc4LFHcC\&pg=SA2-

PA34\&dq=waste+cost+accounting\&hl=ru\&sa=X\&ved=0ahUKEwjq47erw9zaAhWOaFAKHWhEAzQQ6AEIQjAE\#v=onepage\&q=waste \%20cost $\% 20$ accounting \&f=false

36. Robinson, W.D. 1986. The Solid Waste Handbook: A Practical Guide. Retrieved from https://books.google.by/books?id=a4GE5hR7UjYC\&pg=PA179\&dq=waste+cost+accounting\&hl=ru\&sa=X\&ved=0ahUKEwjq47erw9zaA hWOaFAKHWhEAzQQ6AEIWjAH\#v=onepage \&q=waste\%20cost\%20accounting \&f=false

37. Cheremisinoff, P.N. 1995. Waste minimization and cost reduction for the process industries. Retrieved from https://books.google.by/books?id=eywV4fkhTHcC\&pg=PA1\&dq=waste+cost\&hl=ru\&sa=X\&ved=0ahUKEwiF_4rctdzaAhXHbVAKHR7 uB3AQ6AEISTAF\#v=onepage \&q=waste $\% 20 \operatorname{cost} \& \mathrm{f}=$ false

38. Ivanova, M.D. 2005. Accounting of costs for environmental activities. Retrieved from http://www.dissercat.com/content/bukhgalterskiiuchet-zatrat-na-prirodookhrannuyu-deyatelnost

39. Nasakina, L.A. 1999. Features of accounting of costs for environmental protection activities at chemical industry enterprises. Retrieved from http://www.dissercat.com/content/osobennosti-bukhgalterskogo-ucheta-zatrat-na-prirodookhrannuyu-deyatelnost-napredpriyatiyak

40. Brylev, A.N. 1983. Ways to improve the accounting and analysis of the costs of environmental protection in manufacturing enterprises (associations) (for example, the chemical industry). Retrieved from http://www.dissercat.com/content/puti-sovershenstvovaniya-ucheta-ianaliza-zatrat-na-okhranu-okruzhayushchei-sredy-v-proizvod 
The International Journal

ISSN 2345-0282 (online) http://jssidoi.org/jesi/

2018 Volume 6 Number 1 (September)

http://doi.org/10.9770/jesi.2018.6.1(13)

41. Chhutiashvili, L.V. 2010. Issues of accounting and analysis of costs for environmental measures, International accounting 12(144): 830. https://cyberleninka.ru/article/v/voprosy-buhgalterskogo-ucheta-i-analiza-zatrat-na-prirodoohrannye-meropriyatiya

42. Tysyakova, Z.S., Chertkova, A.A. 2009. Classification of environmental costs in modern accounting, Вестник ОГУ 8(102): 111-116. https://cyberleninka.ru/article/n/klassifikatsiya-ekologicheskih-zatrat-v-sovremennom-buhgalterskom-uchete

43. Jasch, Ch. 2009. Environmental and material flow cost accounting. Retrieved from https://books.google.by/books?id=se6TreyGSyUC\&pg=PA47\&dq=waste+cost+accounting\&hl=ru\&sa=X\&ved=0ahUKEwi5pewutzaAhWKLVAKHTqvD6kQ6AEIYDAI\#v=onepage\&q=waste\%20cost\%20accounting\&f=false

44. D'Onza, G., Greco, G., Allegrini, M. 2016. Full Cost Accounting in the Analysis of Separated Waste Collection Efficiency: A Methodological Proposal. Retrieved from https://books.google.by/books?id=lsAstAEACAAJ\&dq=waste+cost+accounting\&hl=ru\&sa=X\&ved=0ahUKEwj2t7q8utzaAhVKaFAKHfn OBFo4ChDoAQg5MAM

45. Jachnik, R. 2006. Assessing the practical relevancy of environmental cost accounting for industrial waste Waste accounting, process $\begin{array}{lllll}\text { efficiency and cleaner } & \text { production. } & \text { Retrieved }\end{array}$ https://lup.lub.lu.se/luur/download?func=downloadFile\&recordOId=1329403\&fileOId=1329404

46. Passarini, K.C., Pereira, M.A., Farias, T.M. de B., Calarge, F.A., Santana, C.C. 2014. Assessment of the viability and sustainability of an integrated waste management system for the city of Campinas (Brazil), by means of ecological cost accounting, Journal of Cleaner Production, Vol. 65: pp. 479-488

47. Woodard \& Curran, Inc. 2006. Industrial Waste Treatment Handbook. Retrieved from https://books.google.by/books?id=H1CAb3Nx35wC\&pg=PA72\&dq=industrial+waste+accounting\&hl=ru\&sa=X\&ved=0ahUKEwi04IjH2t zaAhXQI1AKHY3QAzEQ6AEIJjAA\#v=onepage \&q=industrial\%20waste\%20accounting \&f=false

48. Wang, L.K., Hung, Y-T., Lo, H.H., Yapijakis, C. 2007. Hazardous Industrial Waste Treatment. Retrieved from https://books.google.by/books?id=wDlmB9FBrJsC\&pg=PA5\&dq=industrial+waste+accounting \&hl=ru\&sa=X\&ved=0ahUKEwi04IjH2tza AhXQI1AKHY3QAzEQ6AEILjAB\#v=onepage\&q=industrial\%20waste\%20accounting \&f=false

49. Gricishen, D.O. 2015. Accounting in the management system of economic and environmental safety of industrial enterprises. Zhitomir: Published by ЖДТУ.

50. Pronin, S.I. 2004. Development of an organizational and economic mechanism for implementing a cleaner production strategy at industrial enterprises in Russia. Retrieved from http://www.dissercat.com/content/razrabotka-organizatsionno-ekonomicheskogomekhanizma-realizatsii-strategii-bolee-chistogo-p

51. Volynkina, E.P. 2007. Development of the concept of waste management and development of a methodology for its implementation at a metallurgical enterprise. Retrieved from http://www.dissercat.com/content/razvitie-kontseptsii-upravleniya-otkhodami-i-razrabotkametodologii-ee-realizatsii-na-metall

52. Rubanova, N.N. 2005. Environmental accounting at construction materials industry enterprises. Retrieved from http://www.dissercat.com/content/ekologicheskii-uchet-na-predpriyatiyakh-promyshlennosti-stroitelnykh-materialov

53. Grosheva, M.A. 2006. Innovative investment support for the processing of oily waste. Retrieved from http://www.dissercat.com/content/innovatsionno-investitsionnoe-obespechenie-pererabotki-neftesoderzhashchikh-otkhodov

54. Umerov, R.Z. 2000. Mechanisms for the economic improvement of industrial waste management in the region. Retrieved from http://www.dissercat.com/content/mekhanizmy-ekonomicheskogo-sovershenstvovaniya-upravleniya-promyshlennymi-otkhodami-v-region

55. Lapytova, O.V. 2004. Economic and ecological analysis of the enterprise: theory, methodology, methodology and organization. Retrieved from http://www.dissercat.com/content/ekonomiko-ekologicheskii-analiz-deyatelnosti-predpriyatiya-teoriya-metodologiya$\underline{\text { metodika-i-o }}$

56. Cheysova, M.P. 1984. Perfection of statistics of industrial wastes (on an example of the enterprises of Khabarovsk territory). Retrieved from http://www.dissercat.com/content/sovershenstvovanie-statistiki-promyshlennykh-otkhodov-na-primere-predriyatii-khabarovskogo-k 
57. Petukhov, V.I., Litvinec, O.L., Taskin, A.V., Holodov, A.S., Ivannikov, S.I. 2016. System of industrial waste accounting and recycling in Primorsky Territory, Russia in the context of European experience, International Journal of Environmental and Science Education, Vol. 11(Issue 18): pp. 12604-12612

58. Antanenkova, E.A. 2012. Industrial waste: accounting and tax accounting, Accounting, Vol. 12: pp.24-29

59. Panchenko, T.M. 2016. Industrial waste: accounting and tax accounting, Accounting, Vol. 1: pp.37-40

60. The Law of the Republic of Belarus on July 20, 2007 № 271-3 “On waste management”

61. Decision of The Council of Ministers of The Republic of Belarus on October 23, 2009 No. 1391 "On Approval of the List of Hazardous Wastes, Transactions on the Transfer of which for a specified period (except for the contract of carriage), as well as alienation of which to another legal entity or individual entrepreneur handling waste, are subject to registration"

62. Decree of the Ministry of Economy of the Republic of Belarus, the Ministry of Architecture and Construction of the Republic of Belarus, the Ministry of Industry of the Republic of Belarus on June 15, $2006 \mathrm{~N} \mathrm{98/12/10} \mathrm{"On} \mathrm{approval} \mathrm{of} \mathrm{The} \mathrm{Instruction} \mathrm{on} \mathrm{the}$ accounting, storage, use and sale of ferrous and non-ferrous metals, their scrap and waste"

63. State Standard of the Republic of Belarus STB 2026-2010. Secondary black metals. General specifications

64. Technical Code of Good Practice 17.11-10-2014 "Environmental Protection and Nature Management Waste: Rules for the Management of Construction Waste"

65. Resolution of the Ministry of Natural Resources and Environmental Protection of the Republic of Belarus on November 8, 2007 No. 85 "On Approval of the Classifier of Wastes Formed in the Republic of Belarus"

66. The Instruction on Waste Management of petrochemical enterprise OJSC "Naftan"

67. Order of the Ministry of Economy of the Republic of Belarus on October 11, 1999 №99

68. GOST 30773-2001 "Resource-saving. Waste management. Stages of the technological cycle", adopted by the Interstate Council for Standardization, Metrology and Certification (Minutes No. 19 of May 24, 2001)

69. ISO 14001 Environmental management

70. Law of the Republic of Belarus on July 12, 2013 No 57-Z [Amended as of June 4, 2015] "On Accounting and Reporting”

71. Order of the Ministry of Industry of the Republic of Belarus No. 273 on June 5, 2015 "On Approving Methodological Recommendations for Forecasting, Accounting and Calculating the Cost of Products (Goods, Works, Services) in Industrial Organizations of the System of the Ministry of Industry of the Republic of Belarus"

72. Sushko, V.A. 2018. Construction waste of the petrochemical complex at the technological cycle stages of waste under the application conditions of environmental technologies of their disposal and recycling, Accounting, analysis and auditing, Vol. 4(256): pp. 34-40 
Svetlana VEGERA is the Doctor of Economics, professor habil. and the First Vice-Rector of Polotsk State University. Research interests: problems of economic analysis and control development in the context of sustainable development, methodology of accounting for natural capital, corporate social reporting, accounting development in the context of "green economy".

ORCID ID: orcid.org/0000-0002-5717-6109

Alena MALEI is the candidate of economic sciences, associate professor, the head of the department of accounting and auditing, logistics and management. Research interests: financial logistics, logistic costs, sustainable urban mobility, the development of accounting in waste management in the context of "curcular economy", sustainable development.

ORCID ID: orcid.org/0000-0002-5331-0032

Ina SAPEHA is the candidate of economic sciences, associate professor of the department of accounting and auditing, logistics and management. Research interests: accounting for assets and liabilities of the organization, risks in the accounting system, financial indepence and industrial waste management.

ORCID ID: orcid.org/0000-0003-0205-0880

Volha SUSHKO is the assistant the department of accounting and auditing, logistics and management, master of Economic Sciences. Research interests: accounting and analytical support of financial independence management, industrial waste accounting in petrochemical complex in the context of "green economy", assesment issues of indusdtrial waste.

ORCID ID: orcid.org/0000-0001-5036-2200

Register for an ORCID ID:

https://orcid.org/register

Copyright (C) 2018 by author(s) and VsI Entrepreneurship and Sustainability Center

This work is licensed under the Creative Commons Attribution International License (CC BY).

http://creativecommons.org/licenses/by/4.0/

CC) (i) Open Access 